Prof. Matthew Woodcock,

School of Literature, Drama \& Creative Writing,

University of East Anglia,

Norwich, NR4 7TJ

\title{
UNACKNOWLEDGED USES OF MONTAIGNE'S ESSAIS IN SIR CLEMENT EDMONDES'S OBSERVATIONS ON THE COMMENTARIES OF JULIUS CAESAR
} (1600-1609)

To the long list of late sixteenth- and early seventeenth-century English authors for whom evidence has been assembled concerning their reading, use, or citation of Michel de Montaigne's Essais, we can add Sir Clement Edmondes, the translator-annotator of Julius Caesar's Commentaries. ${ }^{1}$ Caesar produced seven books of commentarii concerning expeditions made into Gaul and beyond between 58-52 BC - a text usually known as De Bello Gallico — and three books on the civil war (De Bello Civili) waged against Pompey

\footnotetext{
${ }^{1}$ Edmondes's Observations have attracted limited critical attention to date: see Robert C.
} Evans, Habits of Mind: Evidence and Effects of Ben Jonson's Reading (Lewisburg: Bucknell University Press, 1995), ch. 7; David R. Lawrence, The Complete Soldier: Military Books and Military Culture in Early Stuart England, 1603-1645 (Leiden: Brill, 2009), 145-7; Edward Paleit,War, Liberty, and Caesar: Responses to Lucan's Bellum Civile', c.1580-1650 (Oxford: Oxford University Press, 2013), 111-23; Matthew Woodcock, “"The Breviarie of Soldiers”: Julius Caesar's Commentaries and the Fashioning of Early Modern Military Identity', in Early Modern Military Identities, ed. Matthew Woodcock and Cian O’Mahony (Woodbridge: Boydell and Brewer, forthcoming 2019). 
between 49-48 BC. Edmondes's annotated translation of the first five books of De Bello Gallico appeared in 1600, followed by the seven-book edition in 1604 and the addition of his De Bello Civili translation in 1609. Edmondes combined careers as a scholar, civic official, and statesman with practical and literary interests in military affairs. ${ }^{2}$ In 1600 he dedicated Observations upon the Five First Bookes of Caesars Commentaries to Sir Francis Vere, the foremost English general of the late Elizabethan era. In doing so, he acknowledged not only his patron's 'continued incouragement' of the translation project but also the text's utility among Vere's military circle, declaring 'this worke of Caesar hath alwaies beene held in your particular recommendation, as the Breviarie of soldiers' ${ }^{3}$

When composing his annotations and 'observations' upon Caesar's text Edmondes drew upon his extensive reading in classical and contemporary history and military theory. One important source for the Observations that Edmondes never acknowledges is Montaigne's Essais. Edmondes's unacknowledged borrowings from the Essais have gone unnoticed in previous studies of Montaigne's English reception, ${ }^{4}$ and in scholarship that

${ }^{2}$ Stephen Porter, 'Sir Clement Edmondes', ODNB; 'Sir Clement Edmondes', in The History of Parliament: The House of Commons 1604-1629, ed. Andrew Thrush and John P. Ferris. 6 vols. (Cambridge: Cambridge: University Press, 2010), IV, 166-7.

${ }^{3}$ Sir Clement Edmondes, Observations upon the Five First Bookes of Caesars Commentaries (London, 1600), sig. *2r.

${ }^{4}$ Grace Norton, The Spirit of Montaigne: Some Thoughts and Expressions Similar to Those in His Essays (Boston: Houghton, Mifflin, 1908); Norton, Montaigne: His Personal $\underline{\text { Relations to Some of His Contemporaries, and His Literary Relations to Some Later }}$ Writers (Boston: Houghton, Mifflin, 1908); Pierre Villey, 'Montaigne en Angleterre',

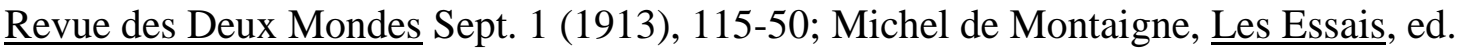


focuses on Montaigne's sustained, if ambiguous engagement with Caesar's

Commentaries. ${ }^{5}$ As noted above, Edmondes attributes the description of the Commentaries as being the breviary of every fighting man to his dedicatee Vere:

this worke of Caesar hath alwaies beene held in your particular recommendation, as the Breviarie of soldiers; and thought worthie of as great regard, as ever M. Brutus attributed to Polybius, or Charles the fift to Philip de Commines. ${ }^{6}$

Pierre Villey and V.L. Saulnier (Paris : Presses Universitaires de France, rpt. 1978), Appendix 1; William M. Hamlin, Montaigne's English Journey: Reading the Essays in Shakespeare's Day (Oxford: Oxford University Press, 2013); Warren Boutcher, 'Montaigne in England and America', in The Oxford Handbook of Montaigne, ed. Philippe Desan (Oxford: Oxford University Press, 2016), 306-27; Boutcher, The School of Montaigne in Early Modern Europe, 2 vols. (Oxford: Oxford University Press, 2017). ${ }^{5}$ James J. Supple, Arms Versus Letters: The Military and Literary Ideals in the 'Essais' of

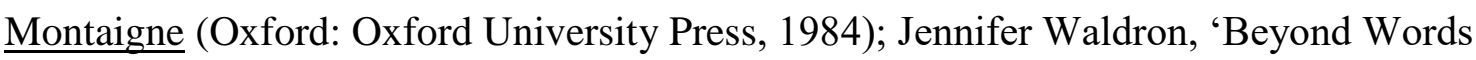
and Deeds: Montaigne's Soldierly Style', Philological Quarterly 82 (2003), 38-59; Louisa Mackenzie, 'Imitation Gone Wrong: The "Pestilentially Ambitious" Figure of Julius Caesar in Michel de Montaigne's Essais', in Julius Caesar in Western Culture, ed. Julia Wyke (Oxford: Wiley-Blackwell, 2006), 129-47; Carol Clark, 'Some Renaissance Caesars', in A Companion to Julius Caesar, ed. Miriam Griffin (Oxford: Wiley-Blackwell, 2009), 365-9; Roger B. Manning, War and Peace in the Western Political Imagination: From Classical Antiquity to the Age of Reason (London: Bloomsbury, 2016), 200-203. ${ }^{6}$ Edmondes, Observations (1600), sig. *2r. 
This description of Caesar's text was actually first given by Montaigne at the beginning of his essay entitled 'Observation sur les moyens de faire la guerre, de Julius Caesar' ('Observations on Julius Caesar's methods of waging war'):

On récite de plusieurs chefs de guerre, qu'ils ont eu certains livres en particulière recommandation, comme le grand Alexandre, Homere: Scipion Africain, Xenophon: Marcus Brutus, Polybius: Charles cinquième, Philippe de Comines. Et dit-on, de ce temps, que Machiavel est encore ailleurs en crédit. Mais le feu Maréchal Strossi, qui avait pris Caesar pour sa part, avait sans doute bien mieux choisi: car, à la vérité, ce devrait être le bréviaire de tout homme de guerre, comme étant le vrai et souverain patron de l'art militaire. ${ }^{7}$

(We read that many leaders in war held particular books in special esteem: Alexander the Great esteemed Homer; Scipio Africanus, Xenophon; Marcus Brutus, Polybius; Charles V, Philippe de Comines. And it is said that in these our days there are others who still think highly of Machiavelli, though the late Marshall Strozzi who took Caesar for his book had without any doubt made the much better choice; truly Caesar ought to be the breviary of every fighting-man: he was the true and sovereign model for the art of war. $)^{8}$

\footnotetext{
${ }^{7}$ Michel de Montaigne, Les Essais, eds J. Céard, D. Bjaï, B. Boudou and I. Pantin (Paris: Livre de Poche, 2001), 1143-4.

${ }^{8}$ Michel de Montaigne, The Complete Essays, trans. M. A. Screech (London: Penguin, 2003), 833.
} 
As is clear from the quotation above, Edmondes also re-appropriates the opening lines of Montaigne's essay about 'chefs de guerre' holding particular books in 'particulière recommandation', so as to link Vere's use of Caesar to Marcus Brutus's high regard for Polybius and that of Charles V for Commines. ${ }^{9}$

Elsewhere, Edmondes closely adapts (in translation) a paragraph from Montaigne commending swimming 'as a thing of much consequence in the use of Armes':

When the ancient Greeks would note a man of extreame insufficiencie; they would say he could neither reade nor swim: So Caesar seemed of the same opinion, by commending the skill of swimming, as a thing of much consequence in the use of Armes. Whereof he made good experience in Egypt; where he cast himselfe into a small boate, for his better safetie: and finding it over-charged, and ready to sinke, he leapt into the sea, and swom to his Fleet, which was 200 pases off, holding certaine papers in his left hand, above the water; and trayling his coate of Armes in his teeth, that it might not be left to the enemie. ${ }^{10}$

Compare this to Montaigne's text:

Quand les anciens Grecs voulaient accuser quelqu'un d'extrême insuffisance, ils disaient en commun proverbe, qu'il ne savait ni lire ni nager: il avait cette même

\footnotetext{
${ }^{9}$ Edmondes does not appear to have drawn on Montaigne's other essays that dwell at length on Caesar: 'D'un Mot de Caesar' and 'L'Histoire de Spurina'.

${ }^{10}$ Sir Clement Edmondes, Observations upon Caesars Commentaries (London, 1609), sig. G4r.
} 
opinion, que la science de nager était très utile à la guerre, et en tira plusieurs commodités: s'il avait à faire diligence, il franchissait ordinairement à nage les rivières qu'il rencontroit: car il aimait à voyager à pied, comme le grand Alexandre. En Aegypte, ayant été forcé, pour se sauver, de se mettre dans un petit bateau, et tant de gens s'y étant lancés quant et lui, qu'il était en danger d'aller à fond, il aima mieux se jeter en la mer, et gagna sa flotte à nage, qui était plus de deux cents pas au-delà, tenant en sa main gauche ses tablettes hors de l'eau, et traînant à belles dents sa cotte d'armes, afin que l'ennemi n'en jouît. ${ }^{11}$

Edmondes also incorporates Montaigne's essay 'De le bataille de Dreux' into an observation on the dangers of pursuing a routed enemy. ${ }^{12}$ Illustrating a point about the role of reason and passion at a Roman war council, Edmondes concludes that 'so powerfull is passion in the government of the soule, and so interested in the other faculties. And this is one cause of the uncertainty of man's judgement'. ${ }^{13}$ He then quotes the same lines from Marcus Manlius that are cited at the end of Montaigne's essay 'De l'incertitude de notre jugement' ('On the uncertainty of our judgment'). ${ }^{14}$

Edmondes works from Montaigne directly from as early as the 1600 Observations. There is no evidence to suggest he was using an early state of John Florio's translation of Montaigne, first published in 1603, although Edmondes and Florio did have a mutual friend in Samuel Daniel. When listing historical precedents of military men and their

\footnotetext{
${ }^{11}$ Montaigne, Les Essais, 1154-5.

${ }^{12}$ Montaigne, Les Essais, 445-7; Edmondes, Observations (1609), sigs. P4r-P4v.

${ }^{13}$ Edmondes, Observations (1609), sig. Z3v.

${ }^{14}$ Montaigne, Les Essais, 466.
} 
favoured textual authorities at the start of 'Observation sur les moyens de faire la guerre, de Julius Caesar', Montaigne gives the example of four such figures in all but the first edition of the Essais, published in 1580, in which he lists three (omitting Scipio Africanus). Edmondes lists only two examples when he draws upon this part of Montaigne's essay in the Observations (Marcus Brutus and Charles V), which may suggest that he worked from the 1580 Essais or else simply preferred not to imitate Montaigne's copiousness when it came to listing authorities or examples.

Edmondes's lack of attribution to Montaigne of the passages quoted above is hard to explain, although unidentified appropriations are themselves another way in which Edmondes evokes Montaigne. Edmondes's evident debt to Montaigne provides a significant indication of how Edmondes went about reading his source text and producing the Observations. Taking his cue from Montaigne, and feasibly from the first edition of Francis Bacon's Essays (1597), Edmondes frequently uses annotation, not simply to add explanatory historical or topographical information, but to reflect on a range of matters and problems prompted by his reading of Caesar. One can imagine that individual sections of Edmondes's observations developed out of annotations made at an intermediate stage between his reading of Caesar's text and composition of the Observations themselves. As such, the Observations offer a valuable contribution to the history of the English essay form — especially regarding how the essay might be used and composed—as we see Edmondes drawing on Montaigne's example when using an informed close reading of the Commentaries as the basis for his own original meditations on a wide range of matters both military and civil. Was, indeed, Edmondes recalling the title of Montaigne's essay on Caesar when naming his own passages of observations on the Commentaries, and thus the overall title of his annotated translation? Edmondes also represents an early English example of what Warren Boutcher terms a 'reader-author' of Montaigne, and an 
important - though hitherto overlooked — example of how a late Elizabethan translatorannotator thought with, and (as Boutcher puts it) told other stories with, the Essais. ${ }^{15}$

As a final note on Edmondes's use of formal terminology, it should be emphasized that although he was calling his Observations his 'Essayes' by 1604, he does so as a way of designating them as literary endeavours or exercises, just as Samuel Daniel does with his 1599 Poeticall Essayes. ${ }^{16}$

MATTHEW WOODCOCK

University of East Anglia

${ }^{15}$ Boutcher, School of Montaigne, II, 4.

${ }^{16}$ Samuel Daniel, The Poeticall Essayes (London, 1599). 